- FINANSE I PRAWO FINANSOWE.

- Journal of Finance and Financial Law

Wrzesień/September 2018 • vol. 3(19): 67-77

https://doi.org/10.18778/2391-6478.3.19.06

\title{
EFEKTYWNOŚĆ INWESTYCJI NA RYNKU KRYPTOWALUT I INWESTYCJI NA RYNKU GIEŁDOWYM - UJĘCIE PORÓWNAWCZE
}

\author{
Dominika Wyderka, Tomasz Saganowski \\ Wydział Ekonomiczno-Socjologiczny \\ Uniwersytet Łódzki
}

\begin{abstract}
Streszczenie
W internetowym świecie coraz częściej wykorzystywane są systemy wirtualnych walut. Do najbardziej popularnych i zdecentralizowanych należy bitcoin. Celem artykułu będzie ocena opłacalności inwestycji na dwóch różnych rynkach - giełdowym oraz rynku kryptowalut. W pracy podjęto również próbę scharakteryzowania kryptowaluty bitcoin.
\end{abstract}

Słowa kluczowe: bitcoin, kryptowaluta, blockchain, waluta cyfrowa.

JEL Class: D53, F39, G14. 


\section{WPROWADZENIE}

Od lat 90-tych poprzedniego stulecia zarówno na świecie, jak i w Polsce można zaobserwować dynamiczny rozwój technologii. Postęp w dziedzinie bankowości przyczynił się do znaczących zmian na rynku finansowym. Przyczyną owych zmian było poszukiwanie szybkich metod upłynniania gotówki, poszukiwano wygodniejszego sposobu przekazywania środków pieniężnych, nie tylko w walutach krajowych. Doprowadziło to do wprowadzenia wielu usprawniających procesy rozwiązań. Istotny przełom na rynku walutowym miał miejsce w 2009 roku. Wtedy została wprowadzona pierwsza na świecie kryptowaluta - bitcoin. Kolejne lata pokazały, że społeczeństwu brakowało globalnej waluty, która oparta jest na całkowicie innych regułach niż dotychczasowe waluty.

Celem artykułu jest porównanie opłacalności inwestycji na dwóch różnych rynkach w latach 2011-2017. Jednym z nich jest światowy rynek kryptowalut, drugim jest Warszawski Indeks Giełdowy - WIG. Sformułowana została hipoteza badawcza, jako stwierdzenie, iż inwestycje poczynione na rynku kryptowalut umożliwiają osiągnięcie większych zysków, niż inwestycje na rynku giełdowym.

Analizie i ocenie poddano stopy zwrotu z inwestycji oraz odchylenie standardowe dziennych stóp zwrotu . O ile badanie rynku giełdowego nie przysparza większych trudności, o tyle analiza i ocena kryptowalut nie jest prosta, ponieważ kierują się one odmiennymi zasadami, w porównaniu do zasad panujących na rynku podstawowym.

\section{BITCOIN JAKO KRYPTOWALUTA}

Kryptowaluta to nowoczesny, elektroniczny środek płatniczy. Jest używana do zabezpieczenia transakcji. Popularność kryptowalut wzrasta z dnia na dzień, a obrót na giełdach to około 25 milionów złotych dziennie. Wirtualne waluty mają kilka swoistych cech [Kusaj: 2, dostęp: 25.03.2018]:

- nie posiadają centralnego emitenta;

- są „wydobywane” przez tzw. „koparki” - nawiązanie do wydobywania prawdziwych kruszców tj. złoto, srebro;

- powstają w efekcie sieci, które wykorzystują matematyczny skrypt;

- twórcy cyfrowych walut w swoich postanowieniach założyli, że nie będzie możliwości emitowania dodatkowych jednostek cyfrowych;

- transakcje wirtualnymi walutami są anonimowe.

Pierwszą, a zarazem najpopularniejszą, kryptowalutą jest bitcoin. Został wypuszczony na rynek w 2009 roku. Twórcą tej waluty jest Satoshi Nakamoto. 
Nie wiadomo jednak, czy jest to pseudonim jednej osoby czy grupy ludzi. Nazwa odnosi się do otwartego oprogramowania oraz sieci peer-to-peer. W odróżnieniu do tradycyjnych walut, Bank Centralny nie ma nadzoru nad kryptowalutami. Bitcoiny mogą zostać przesłane do innej osoby przez Internet. Każdy bitcoin jest podzielny na 100000000 mniejszych jednostek, które są nazywane satoshi [Lis Markiewicz i Nowak 2015: 11].

Bitcoin używa zdecentralizowanej bazy danych, w celu zapewnienia funkcji bezpieczeństwa. Pierwsza transakcja na rynku kryptowalut odbyła się w Stanach Zjednoczonych w 2010 roku. W Polsce bitcoin zadebiutował w 2011 roku. Wtedy została otwarta pierwsza giełda, na której za polską walutę można było nabyć bitcoina. Ogromny popyt na kryptowaluty rozpoczął się w momencie, gdy na Cyprze ogłosił bankructwo jeden z największych banków i wielu ludzi straciło majątki. Od tamtej pory przybywa firm, które akceptują płatności walutami cyfrowymi. W wyniku tych zdarzeń nastąpił wzrost liczby rodzajów kryptowalut. Obecnie jest ich około 400 [Kusaj: 3, dostęp: 25.03.2018].

Budowa bitcoina pozwala na anonimowe posiadanie własności oraz transferu. Jest oparta na przekazie kwot między rachunkami przy użyciu kryptografii klucza publicznego. Wszystkie transakcje są przechowywane w bazie danych i mają publiczny charakter [Szymankiewicz 2014: 21-22].

Korzyści z używania cyfrowych walut jest wiele [Kusaj: 3, dostęp: 25.03.2018]:

- szybkość transakcji - maksymalnie trwają do 30 minut;

- niska cena transakcji (około 10 groszy), bądź darmowe transakcje;

- anonimowość transakcji - rozpoznawalny jest tylko specjalny adres, w którym nie trzeba podawać danych personalnych;

- polityka państwa nie ma kontroli nad ilością kryptowalut, dlatego nie ma możliwości wpływania na jej kurs.

Cyfrowe waluty są względnie nowym zjawiskiem w gospodarce, jednak analizując ich role widoczne jest to, że niektóre funkcje jakie pełnią są zbliżone do funkcji pieniądza. Może być środkiem wymiany płatności, w sytuacji gdy obie strony wyrażą zgodę na płatność walutą cyfrową. Bitcoin posiada również funkcję tezauryzacyjną, gdyż umożliwia przechowywanie wartości w czasie. Co więcej, kryptowaluty są zapisem cyfrowym, co wpływa na ich trwałość i poręczność. Postać cyfrowa zapewnia podział na wiele małych jednostek. Większość walut zapewnia podział do ośmiu miejsc po przecinku [Piotrkowska 2018: 12].

\section{TRANSAKCJE BLOCKCHAIN'A NA PRZYKŁADZIE BITCOINA}

Dogłębne poznanie kryptowalut jest możliwe poprzez zrozumienie technologii blockchain. W 2008 roku na świecie rozpoczął się kryzys finansowy. Dla wielu instytucji finansowych był to ogromny cios. Rozwiązaniem na zapewnienie bez- 
piecznej komunikacji między systemami informatycznymi był projekt Bitcoin. Przełomowa jest koncepcja waluty cyfrowej, ale także technologia pod którą podlega - blockchain [Homa 2015: 43, dostęp: 24.03.2018].

Blockchain to księga zawierająca listę transakcji, w której prowadzone są rozrachunki. Blockchain bitcoinowy rozpoczyna się od wpisu, w którym właściciel danego adresu publicznego wykreował pierwsze bitcoiny. Każdy kolejny wpis zaczyna się od wygenerowania następnej transzy i przydzielenia do wyznaczonego adresu. W blokach zawarte są zapisy dotyczące nowo wygenerowanych bitcoinów, jak również transakcje, które dotyczą monet już powstałych. Bloki, czyli rozdziały księgi posiadają ograniczoną pojemność [Piech 2017: 14-15, dostęp: 25.03.2018].

\section{CHARAKTERYSTYKA WIG JAKO INDEKSU GIEŁDOWEGO}

Indeksy giełdowe ukazują informacje o danej giełdzie. Można z nich odczytać czy rynek dotyczy akcji, czy też obligacji lub z jakiej branży pochodzi dany podmiot (np. bank). Stałe obliczanie indeksów giełdowych umożliwia historyczne analizowanie, w którym zobaczymy długookresowe trendy i zależności oraz rentowność inwestycji w odniesieniu do lat wcześniejszych. Dzięki indeksom można dodatkowo porównać sytuację gospodarczą różnych państw.

Pierwszy raz indeksem posłużono się w 1884 roku. Twórcy założyli, że reakcja kursu akcji danej grupy spółek najlepiej odzwierciedli obecną sytuację na giełdzie. Indeks powinien zostać zbudowany w oparciu o kilka czynników [Błachucki: 1]:

- ma być oparty na reprezentatywnej grupie papierów wartościowych;

- musi bazować na zmianach cen podanych walorów;

- powinien stwarzać wiele możliwości porównania wartości aktualnych $\mathrm{z}$ danymi historycznymi.

Istnieją dwa podstawowe rodzaje indeksów: dochodowe i cenowe. Indeksy dochodowe pozwalają na obserwację łącznej zmiany ceny grupy akcji razem z przypisanymi tym akcjom prawami majątkowymi. Indeksy cenowe opierają się jedynie na odnotowanej zmianie cen akcji.

Obecnie GPW publikuje 22 tego typu wskaźniki i robi to na bieżąco. Wiarygodność indeksu giełdowego zależy od notowanych spółek. Dla tego celu giełda stworzyła bazowe kryteria spółek, wchodzące w skład któregokolwiek indeksu [Błachucki: 1-2, dostęp: 25.03.2018]. 


\section{ZASTOSOWANE METODY BADAWCZE}

Odpowiednia analiza oraz ocena sytuacji finansowej mają fundamentalne znaczenie w przypadku podejmowania decyzji dotyczących inwestycji. Za podstawowe metody oceny można przyjąć oczekiwaną dzienną stope zwrotu oraz odchylenie standardowe dziennej stopy zwrotu. Natomiast miarą, która scali te dwie miary będzie współczynnik zmienności stopy zwrotu.

Niewątpliwie najczęstszym sposobem pomiaru zyskowności inwestycji jest stopa zwrotu. Stanowi stosunek osiągniętego zysku lub straty do zaangażowanego kapitału, a więc pozwala na ocenę opłacalności wybranych inwestycji. Wskaźnik efektywności inwestycji może osiągnąć ujemne wartości. Im wyższa jego wartość, tym większy zwrot z inwestycji [Pera: 12, dostęp: 25.03.2018].

Do analizy zostanie także użyta miara ryzyka, jaką stanowi odchylenie standardowe stopy zwrotu. Odchylenie jest miarą rozproszenia bezwzględnego. Mówi o zmienności obserwowanych wyników, a dokładnie informuje czy rozrzut wokół stopy zwrotu jest wielki czy też nie [Wróbel 2010: 1-2, dostęp: 25.03.2018].

Ostatnią z omawianych miar będzie współczynnik zmienności stopy zwrotu, który pozwoli określić wielkość ponoszonego ryzyka w stosunku do osiągniętego dochodu. Stanowi on iloraz odchylenia standardowego w stosunku do stopy zwrotu. Aby można było odpowiednio obliczyć i zinterpretować wskaźnik, stopa zwrotu nie powinna być ujemna [Nowak 2015: 23].

W pierwszej kolejności analizie poddano szereg dziennych stóp zwrotu bitcoina w stosunku do PLN, zaobserwowanych w okresie od 01.01.2011 do 31.12.2017. Okres ten składa się z 1806 obserwacji w przypadku analizy kursu i zostanie przedstawiony w postaci 1 okresu 7-letniego oraz 7 okresów rocznych. Kolejno zaprezentowane zostanie odchylenie standardowe, w celu zobrazowania powstałych odchyleń od średniej stopy zwrotu, a także wspomniany współczynnik zmienności stopy zwrotu. Aby porównać wyniki kursu wybranej kryptowaluty do wyników całego rynku i wyboru najbardziej optymalnego sposobu inwestycji, posłużono się Warszawskim Indeksem Giełdowym (WIG). Notowania WIG w badanym okresie tworzy 1748 obserwacji.

\section{WYNIKI BADAŃ I ICH ANALIZA}

Stopa zwrotu daje możliwość obserwacji zmiany wartości danej inwestycji w określonym czasie. Jednak, aby we właściwy sposób zaprezentować zmiany kursu BTC/PLN za 1 okres 7-roczny, posłużymy się uśrednioną dzienną stopą zwrotu z całego badanego okresu. 
Tabela 1. Oczekiwana dzienna stopa zwrotu WIG-u i kursu BTC/PLN z okresu 7-letniego [\%]

\begin{tabular}{|c|c|}
\hline Wyszczególnienie & OKRES 7-LETNI \\
\hline BTC/PLN & 0,814 \\
\hline WIG & 0,022 \\
\hline
\end{tabular}

Źródło: Stooq. Obliczenia własne.

Tabela 1, przedstawiająca wynik otrzymany poprzez uśrednienie dziennych stóp zwrotu, pozwala wywnioskować, że gdyby inwestycja toczyła się na przestrzeni tych lat, pozwoliłaby otrzymać przeciętnie 0,814\% dziennego zysku $\mathrm{z}$ inwestycji. Co oznacza, że z każdego zainwestowanego złotego można by uzyskać średnio 0,00814 zł, czyli niespełna 1 grosz.

Warto otrzymany wynik przyrównać do wyniku jaki osiągnęły wszystkie spółki na rynku podstawowym, w celu prezentacji różnicy otrzymanych wartości. Notowania WIG-u zostały przedstawione w analogiczny sposób, a efekty obliczeń przedstawia także tab. 1. Zgodnie z nią w przypadku inwestycji poczynionych na rynku giełdowym, w badanym okresie, średnio można było otrzymać $0,022 \%$ zwrotu z inwestycji, co daje 0,00022 zł zysku z każdego zainwestowanego złotego.

Porównując otrzymane wyniki niewątpliwie widoczna jest dysproporcja oraz silna przewaga kursu kryptowaluty nad wynikami wszystkich spółek rynku podstawowego. Oczekiwana dzienna stopa zwrotu na rynku kryptowaluty jest kilkadziesiąt razy większa niż spółek na rynku podstawowym.

Aby w dokładniejszy sposób przeanalizować badany okres warto spojrzeć na każdy rok (z przedziału 2011-2017) z osobna. Rezultaty obliczeń przedstawia tab. 2 oraz wykres 1.

Tabela 2. Oczekiwana dzienna stopa zwrotu WIG-u i kursu BTC/PLN z 7-okresów rocznych [\%]

\begin{tabular}{|c|c|c|c|c|c|c|c|}
\hline Wyszczególnienie & \multicolumn{7}{|c|}{ 7 OKRESÓW ROCZNYCH } \\
\hline Rok & 2011 & 2012 & 2013 & 2014 & 2015 & 2016 & 2017 \\
\hline BTC/PLN & 1,618 & 0,430 & 1,928 & $-0,242$ & 0,267 & 0,375 & 0,837 \\
\hline WIG & $-0,081$ & 0,100 & 0,379 & 0,003 & $-0,044$ & $-0,211$ & 0,088 \\
\hline
\end{tabular}

Źródło: Stooq. Obliczenia własne.

Analizując oczekiwaną dzienną stopę zwrotu WIG-u i kursu BTC/PLN z 7-okresów rocznych uwagę przykuwa rok 2013, w którym przeciętna dzienna stopa zwrotu kursu BTC/PLN wyniosła aż 1,928 \% oraz rok $2011 \mathrm{z}$ wynikiem$1,618 \%$. 


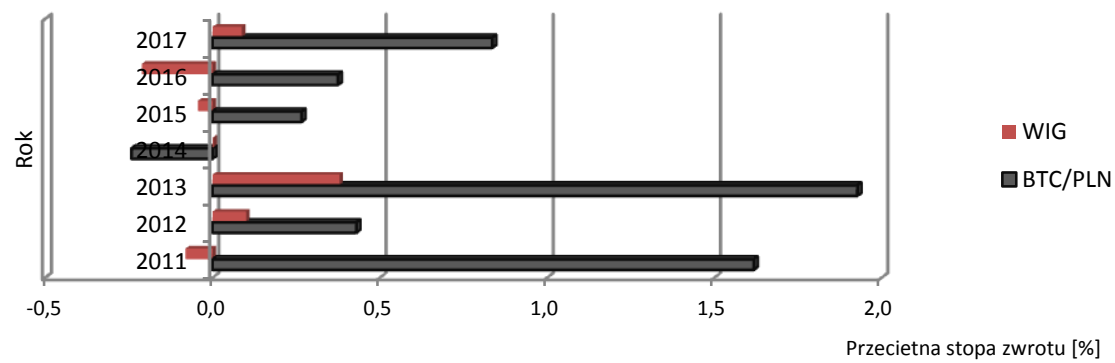

Wykres 1. Oczekiwana dzienna stopa zwrotu WIG-u i kursu BTC/PLN z 7-okresów rocznych [\%]

Źródło: Stooq. Na podstawie obliczeń własnych.

W roku 2011 roku opublikowano pierwszy artykuł o bitcoinie w poważnych mediach, a dokładnie w amerykańskim tygodniku Time, w tym czasie wybuchła także pierwsza bitcoinowa bańka. Rok 2013 to już dwie bańki bicoinowe oraz akceptacja tej kryptowaluty w Niemczech jako pełnoprawnego pieniądza prywatnego i zwolnienie z podatku w przypadku obrotu bitcoinami w Danii [Lyon 2017, dostęp: 25.03.2018]. Te dwa lata w ogromny sposób wpłynęły na wynik dziennej stopy zwrotu z całego 7-letniego okresu badawczego. Tak wysokie stopy zwrotu są spowodowane ogromnymi i gwałtownymi wzrostami wartości notowań bitcoina. Jedyny rok, w którym zaobserwowano ujemną stopę zwrotu to rok 2014, z wynikiem $-0,242 \%$, przyniósł on upadek największej giełdy omawianej krypto waluty - Mt. Gox. Jest to tym samym jedyny przedział czasu, w którym oczekiwana stopa zwrotu Warszawskiego Indeksu Giełdowego była wyższa, a tym samym korzystniejsza.

Warto jednak zwrócić uwagę, że w ciągu 7-letniego badanego okresu cena BTC wzrosła z 87 groszy (notowanie z 1 dnia obserwacji) do 49228 PLN (notowanie $\mathrm{z}$ ostatniego dnia obserwacji). Zauważyć można, że wzrost stopy zwrotu jest zależny od aprobaty wszelkich instytucji i państw (zwłaszcza tych o silnych gospodarkach), które w tych latach zaakceptowały płatność bitcoinem, jak np.: Chiny, Japonia czy wspomniane już Niemcy. Dodatkowo wpływ na notowania ma coraz większa trudność kopania i przeciążenia sieci. Podaż kryptowalut jest ograniczona, a popyt i zainteresowanie ze strony mediów ciągle rosną [Lyon 2017, 25.03.2018].

Kolejną miarą jaka zostanie użyta do analizy jest odchylenie standardowe. Jest ono niezwykle istotne, zwłaszcza jeżeli analizie jest poddana kryptowaluta, której wartość waha się w znaczący sposób i zastanawiające jest jak, i o ile wartości notowań mogą się różnić od przeciętnej dziennej stopy zwrotu. Tab. 3 przedstawia wyniki obliczeń. 
Tabela 3. Odchylenie standardowe dziennych stóp zwrotu z WIG-u i kursu BTC/PLN $\mathrm{z}$ okresu 7-letniego [w \%].

\begin{tabular}{|c|c|}
\hline Wyszczególnienie & OKRES 7 LETNI \\
\hline BTC/PLN & 6,508 \\
\hline WIG & 1,018 \\
\hline
\end{tabular}

Źródło: Stooq. Obliczenia własne.

Odchylenie standardowe, odnoszące się do całego badanego okresu, przede wszystkim obrazuje jak bardzo różnią się między sobą te dwa rodzaje inwestycji. Znacznie większe rozproszenie występuje w przypadku kursu BTC/PLN. Informuje ono nas o tym, że przeciętnie omawiana wartość różni się o 7 groszy $(0,065 \mathrm{zl})$ od średniej dziennej stopy zwrotu. Wprawdzie nie wydaje się być to duża wartość, jednak biorąc pod uwagę wysokość odchylenia osiągniętego przez Warszawski Indeks Giełdowy, który wynosi 1 grosz ( 0,010 zł $)$ - jest to znaczna wartość.

Warto zwrócić uwagę na wyniki otrzymanych odchyleń standardowych we wszystkich 7 latach oddzielnie. Rezultaty obliczeń przedstawia tab. 4 oraz wykres 2 .

Tabela 4. Odchylenie standardowe dziennych stóp zwrotu z WIG-u i kursu BTC/PLN z 7 okresów rocznych [w \%]

\begin{tabular}{|c|c|c|c|c|c|c|c|}
\hline Wyszczególnienie & \multicolumn{7}{|c|}{ 7 OKRESÓW ROCZNYCH } \\
\hline Rok & 2011 & 2012 & 2013 & 2014 & 2015 & 2016 & 2017 \\
\hline BTC/PLN & 9,977 & 3,354 & 9,437 & 4,780 & 3,399 & 3,185 & 9,430 \\
\hline WIG & 1,542 & 0,873 & 0,356 & 0,811 & 0,942 & 0,228 & 0,738 \\
\hline
\end{tabular}

Źródło: Stooq. Obliczenia własne.

Analizując otrzymane wyniki możemy zaobserwować, że znacznie wyższą wartość odchylenia standardowego dziennej stopy zwrotu uzyskał kurs BTC/PLN. W omawianym przypadku, w każdym z rocznych okresów odchylenie standardowe z WIG-u jest mniejsze od odchylenia kursu walutowego. Istotne jest to, że w przypadku kursu w roku 2011, 2013 i 2016 odnotowano najwyższe wartości zastosowanej miary i wynoszą one niespełna $10 \%$. Tak więc zmienność kursu BTC/PLN jest większa niżeli zmienność Warszawskiego Indeksu Giełdowego, co może oznaczać istnienie większego ryzyka w przypadku tego rodzaju inwestycji. 


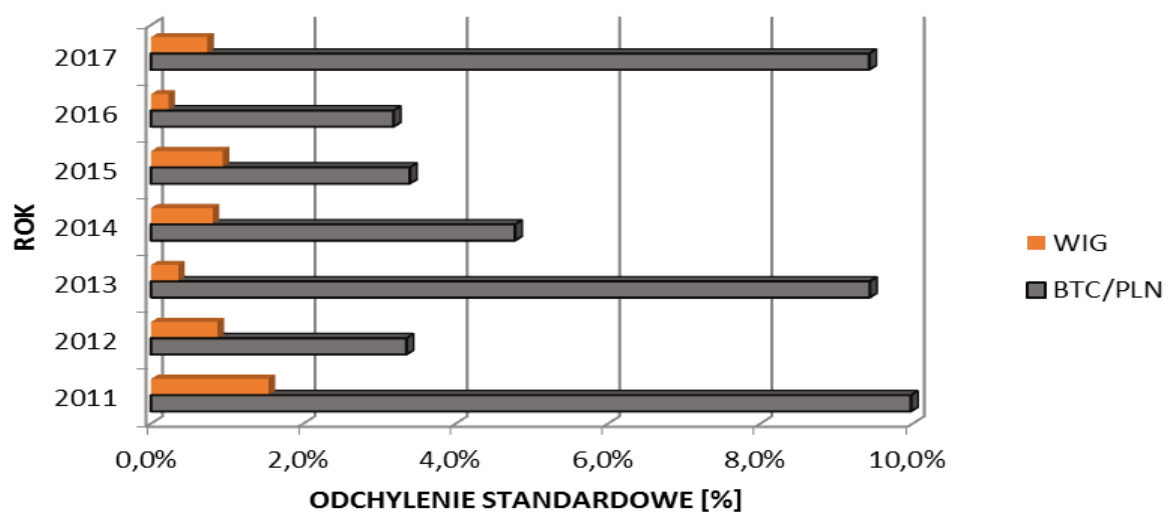

Wykres 2. Odchylenie standardowe dziennych stóp zwrotu z WIG-u i kursu BTC/PLN z 7-okresów rocznych [w \%].

Źródło: Stooq. Na podstawie obliczeń własnych.

Wskaźnik zmienności stopy zwrotu pozwoli wskazać, ile ryzyka przypada na jednostkę stopy zwrotu. Zgodnie z tab. 5 wyższym ryzykiem obarczone są inwestycje na rynku podstawowym, ponieważ w badanym 7-letnim okresie na jednostkę stopy zwrotu przypada około 46 jednostek ryzyka. Oczywistym staje się stwierdzenie, że im niższa wartość wskaźnika tym mniejsze ryzyko.

Tabela 5. Wskaźnik zmienności stopy zwrotu WIG-u i kursu BTC/PLN z okresu 7-letniego

\begin{tabular}{|c|c|}
\hline Wyszczególnienie & OKRES 7-LETNI \\
\hline BTC/PLN & 8 \\
\hline WIG & 46 \\
\hline
\end{tabular}

Źródło: Stooq. Obliczenia własne.

Tabela 6. Wskaźnik zmienności stopy zwrotu WIG-u I kursu BTC/PLN z 7-okresów rocznych

\begin{tabular}{|c|c|c|c|c|c|c|c|}
\hline Wyszczególnienie & \multicolumn{7}{|c|}{ 7 OKRESÓW ROCZNYCH } \\
\hline Rok & 2011 & 2012 & 2013 & 2014 & 2015 & 2016 & 2017 \\
\hline BTC/PLN & 6 & 10 & 5 & - & 17 & 7 & 5 \\
\hline WIG & - & 9 & 1 & 298 & - & - & 8 \\
\hline
\end{tabular}

Źródło: Stooq. Obliczenia własne. 
Analizując natomiast każdy rok oddzielnie, uwagę przykuwa wartość uzyskana w 2014 roku, w którym WIG osiągnął 298 jednostek ryzyka, co przedstawia tab. 6. Wynik ten w znaczny sposób wpływa na wynik miary uzyskany w całym 7-letnim okresie. W pozostałych okresach nie zaobserwowano tak dużych dysproporcji. Warto wspomnieć, że w latach, w których stopa zwrotu osiągnęła ujemne wartości, obliczenie wskaźnika zmienności stopy zwrotu nie było możliwe.

\section{PODSUMOWANIE}

Kryptowaluty są nadal nowym zjawiskiem w dziedzinie finansów. W związku z rosnąca popularnością krytptowalut istnieje prawdopodobieństwo wystąpienia bańki spekulacyjnej. Nieodłączną częścią każdej kryptowaluty jest technologia blockchain. Zapewnia ona bezpieczeństwo oraz transparentność.

Przeprowadzone badania oraz interpretacje mają charakter teoretyczny. Inwestując na rynku trzeba mieć świadomość istniejącego ryzyka, ze względu na złożoność mechanizmów, a także zjawiska gospodarcze i polityczne, które nie zostały uwzględnione w przeprowadzonym badaniu. O ile w przypadku stopy zwrotu wysoka jej wartość jest pożądana, tak w przypadku odchylenia standardowego stopy zwrotu i wskaźnika zmienności stopy zwrotu - niekoniecznie. Oczywiście ocena oraz interpretacja tych ostatnich miar zależy od upodobań inwestora i jego skłonności do podejmowania ryzyka.

Została potwierdzona hipoteza badawcza, stwierdzająca, iż inwestycje poczynione na rynku kryptowalut pozwalają osiągnąć większe zyski, niż inwestycje na rynku giełdowym. Owa inwestycja w cyfrową walutę może oznaczać znaczne pomnożenie zysków. Badając kryptowalutę jaką jest bitcoin udało się wykazać, że należy do rodzajów inwestycji o charakterze niestabilnym. Czynnikiem zniechęcającym większość inwestorów jest ryzyko i niepewność. Jednak należy przyznać, że występuje ono zarówno na rynku podstawowym, jak i na rynku kryptowalut. Niestety niemożliwe jest jednoznaczne stwierdzenie, który rodzaj inwestycji warto wybrać, ponieważ, o ile bitcoin pozwala na osiągnięcie większych zysków, o tyle zastosowane miary ryzyka nie dały jednoznacznej odpowiedzi, co do określenia jednej z nich, mianem bardziej ryzykownej. 


\title{
BIBLIOGRAFIA
}

Błachucki M., Indeksy Giełdowe [online] [w:] http://www.pomocstudentom.pl/pub/dr-mateuszblachucki-indeksy-gieldowe.pdf [dostęp 25.03.2018].

Homa D., 2015, Sekrety Bitcoina $i$ innych Kryptowalut, HELION, Gliwice, [w:] https://www.ticker.pl/2015/08/27/jak-ocenic-efektywnosc-inwestycji-2/ [dostęp 24.03.2018].

Kusaj M., Krypto-waluty w pigutce [online] [w:] http://www.bitcoinwalutaprzyszlosci.pl/wpcontent/uploads/2016/11/Kryptowaluty-w-pigulce.pdf [dostęp 25.03.2018].

Lis Markiewicz P., Nowak Sz., 2015, Bitcoin Przyszłość Inwestowania, Wydawnictwo Naukowe PWN, Warszawa.

Lyon N., 2017, 10 Reasons for Bitcoin Price To Grow To New Heights in 2017 [online] [w:] https://coinidol.com/10-reasons-for-bitcoin-price-to-grow-in-2017 [dostęp 25.03.2018].

Nowak A., 2015, Ocena efektywności przedsięwzięć gospodarczych, Warszawa.

Pera K., Pomiar dochodowości inwestycji - istota, odmiany i cechy stóp zwrotu [online] [w:] https://www.ksiegarnia.beck.pl/media/product_custom_files/1/1/11103-modeleinwestycyjne-krystian-pera-darmowy-fragment.pdf [dostęp 25.03.2018].

Piech K. (red.), 2017, Podstawy korzystania $z$ walut cyfrowych, Instytut wiedzy i innowacji, [online] [w:] https://www.gov.pl/documents/31305/436699/Podstawy+walut+cyfrowych.pdf/7a00 0d7b-2544-f2c7-b532-991a3ee6049a [dostęp 25.03.2018].

Piotrowska A.I., 2018, Bitcoin Ptatnicze i inwestycyjne zastosowania kryptowaluty, CeDeWu, Warszawa.

Szymankiewicz M., 2014, Bitcoin - Wirtualna waluta internetu, Helion, Gliwice.

Wróbel M., 2010, Średnia, odchylenie standardowe i odchylenie standardowe średniej. Inne parametry statystyczne, Uniwersytet Śląski, Katowice, [online] [w:]

http://www.wrobelmaciek.info/sites/default/files/srednia-i-stddev_0.pdf [dostęp 25.03.2018].

\section{EFFECTIVENESS OF INVESTMENTS ON THE CRYPTOCURRENCY MARKET AND INVESTMENTS ON THE STOCK MARKET - A COMPARATIVE APPROACH}

\begin{abstract}
In the online world, virtual currency systems are used more and more often. Bitcoin is the most popular and decentralized ones. The aim of the article is to assess the profitability of investments on two different markets - the stock market and the cryptocurrency market. The work also attempts to characterize bitcoin cryptocurrencies.
\end{abstract}

Keywords: bitcoin, cryptocurrency, blockchain, digital currency. 